\title{
The Influence of Hypnobrithing Techniques on Reducing Anxiety of Third Trimester Mothers During Preparation for Childbirth
}

\author{
Aulia Asman ${ }^{1 *}$,Erpita Yanti ${ }^{2}$, and Autika Asman ${ }^{3}$ \\ ${ }^{1,2,3}$ Associate's Degree of Nursing, Universitas Negeri Padang, Padang, Indonesia \\ *Corresponding author. Email: aulia.asman@gmail.com
}

\begin{abstract}
Pregnancy is a natural thing that happens to women who are productive. During pregnancy there are changes in the mother both physically and psychologically. In Indonesia about $95 \%$ of health workers do not pay much attention to the psychological condition of women giving birth but rather pay attention to the physical condition of the mother and the baby being born. The delivery process has an impact on extreme pain and can cause fear and even death of both the mother and baby. One method that can be used is the Hypnobrithing technique. Hypnobrithing is a practice of self hypnosis (self hypnosis) which is then used to be used in the birthing process. The purpose of this study was to determine the effect of hypnobrithing techniques on the level of anxiety of third trimester mothers during preparation for labor. Type of research Action research uses a One Group Prettest Posttest design approach. The population of the study was 13 third trimester pregnant women. Sampling by total sampling. Univariate and bivariate data processing using computerized paired sample T-Test analysis. The results of the study found that there was an influence of hypnobrithing technique on the level of anxiety in trimester III mothers during preparation for childbirth, $p$ value of 0.001 and an average (Mean) increase in the score of maternal anxiety levels in mothers after intervention amounted to 4,308 . It is expected that pregnant woman should be hypnobrithing this method can be one way to overcome anxiety when facing labor.
\end{abstract}

Keywords: Hypnobrithing, pregmant, woman

\section{INTRODUCTION}

Pregnancy is a natural thing that happens to women who are productive. During being pregnant, there are modifications withinside the mom each bodily and psychologically. In general, physical alterations in the course of being pregnant are, now no longer menstruation, breast expansion, modifications withinside the form of the uterus, changes withinside the workings of organs, development of the stomach, weight gain, weakening of the rest of the muscle tissue of the digestive tract, sensitivity to sensing, and $\mathrm{ft}$ and arms start to enlarge (Pieter \& Lubis, 2010).

Psychological changes in the first trimester mother is estimated at $80 \%$, arising from a sense of disappointment, rejection, anxiety and sadness. In the second trimester of life, psychology of the mother appears calmer and begins to adapt, and in the third trimester, changes in maternal psychology seem more complex and increase again than in the previous trimester, and this is due to the growing condition of pregnancy because it will face childbirth (Janiwarty \& Pieter, 2012). Childbirth is the process by which a baby, the amniotic membrane, comes out of the mother's uterus. Childbirth is considered normal if the process occurs at term of gestational age (after 37 weeks) without any complications (MOH RI, 2008).

Three main factors in childbirth are birth canal (passage), child (passenger), and power (power). During being pregnant, there are modifications withinside the mom each bodily and psychologically. In general, physical alterations in the course of being pregnant are, now no longer menstruation, breast expansion, modifications withinside the form of the uterus, changes withinside the workings of organs, development of the stomach, weight gain, weakening of the rest of the muscle tissue of the digestive tract, sensitivity to sensing, and $\mathrm{ft}$ and arms start to enlarge. There are several factors that influence anxiety in pregnant women, namely decision making, maternal age, family readiness, maternal health and experience (Maimunah, 2011). Pregnant women who are not prepared for childbirth will be more anxious and show fear in a silent behavior to cry. Even though the birth as a physiological phenomenon is normal, in reality the 
process of labor has an impact on bleeding, excessive ache and may motive worry or even loss of life of each the mom or baby (Janiwarty \& Pieter, 2012). One method that can be used is Hypnobrithing. Hypnobrithing is a practice of self hypnosis (self hypnosis) which is then used to be used in the birthing process. The theory underlying Hypnobrithing is a relaxation method that has also been developed by Lanny Kuswandy in Indonesia. According to Lanny, normal delivery should be natural and running smoothly, but the presence of maternal anxiety factors hinders the delivery that should be smooth (Reni \& Henny, 2010). Hypnobrithing can be one way pregnant women practice to be aware of uncomfortable times appearing to later accept it as part of their pregnancy journey. Then try to arrange it so that it does not interfere let alone damage the happiness of the heart while undergoing a pregnancy that was awaited so far. Pregnant women can undergo a healthy and mindful pregnancy. (Kuswandy L, 2014). According to WHO data (2010), as many as 536,000 women die from childbirth. As many as $99 \%$ of maternal deaths due to childbirth or birth problems occur in developing countries. That became one of the causes of anxiety in pregnant women in the face of childbirth.

In Indonesia about $95 \%$ of health workers do not pay much attention to the psychological condition of women giving birth but rather pay attention to the physical condition of the mother and the baby being born. If we pay attention to many women who choose labor with surgery on the basis of certain considerations, especially mothers imagine the pain in the delivery process (Suryani, 2012). In Indonesia there are 373,000,000 pregnant people, who experience anxiety in the face of childbirth as many as $107,000,000$ people. (Ministry of Health Republic of Indonesia, 2015). The phenomenon that exists in some areas of health service practice, not a few maternity mothers who scream and feel confused about the labor process that is being experienced, and generally the health care workers think it is more commonly felt by every mother giving birth. Midwives as health service workers, especially in the field of maternal and child health, are one of the important factors in the delivery process as a helper for labor. It is already a demand that midwives can also become innovators by using the latest methods for caring for mothers, one of which is hypnobirthing. A mother has the right to get high-quality childbirth care so she can avoid discomfort at the time. Based on data from the Padang Pariaman District Health Office in the JanuaryMarch 2017 period, Padang Pariaman District has a total of 8,389 pregnant women. Of the 24 Puskesmas in the Padang Pariaman Regency, the highest number of pregnant women was found in the Lubuk Alung
Puskesmas Work Area. Where in March 2017 there were 748 pregnant women. There are 56 trimester III pregnant women, and the most up to April is 13 in the Lubuk Alung Market Korong. (Padang Pariaman District Health Office, 2017). The results of research conducted by Reni and Henny (2016) Muhammadiyah University of Malang, with the title of the influence of hypnobrithing techniques on the level of anxiety of pregnant women in preparation for childbirth. Obtained from 17 respondents that the outcomes of hysteria tiers of pregnant girls after hypnobirthing rest sporting activities decreased. Proves the effect of hypnobirthing strategies on the extent of hysteria of pregnant girls throughout education for labor. A preliminary survey carried out through researchers on the Lubuk Alung Market Korong withinside the operating region of the Lubuk Alung with Community Health Center, of the five pregnant girls discovered, discovered that indeed pregnant girls who could face childbirth skilled anxiety. Due to many factors, including 2 pregnant women said they had never given birth before, 1 mother said she felt anxious about labor pain during labor and 3 mothers also felt anxious if in labor there were complications of labor and heard cases of death that occurred in postpartum mothers.

\section{METHODS}

The research design used is Pre-Experimental. By comparing the results before (pre-test) and after (posttest) given a treatment called the One Group Prettest Posttest design.

\section{RESULT AND DISCUSSION}

\section{A. Result}

Table 1. Age Frequency Distribution of Respondents by Age in Korong Lubuk Alung Market working area of Lubuk Alung Health

\begin{tabular}{|l|l|l|l|}
\hline No & Age & Frequency & \% \\
\hline 1 & $36-40$ & 2 & 15.4 \\
\hline 2 & $31-35$ & 2 & 15.4 \\
\hline 3 & $26-30$ & 6 & 46.1 \\
\hline 4 & $20-25$ & 3 & 23.1 \\
\hline \multicolumn{2}{|c|}{ Total } & 13 & 100 \\
\hline
\end{tabular}

Table 1 shows that from 13 respondents, 6 people $(46.1 \%)$ were in the age range of $26-30$ years.

Table 2. Frequency Distribution of Respondents by Age of Pregnancy in Korong Lubuk Alung Market working area of the Lubuk Alung Health Center in 2017

\begin{tabular}{|l|l|l|l|}
\hline No & Age of pregnancy & Frequency & \% \\
\hline 1 & 28 weeks & 5 & 38.5 \\
\hline 2 & 29 weeks & 1 & 7.7 \\
\hline 3 & 32 weeks & 6 & 46.2 \\
\hline 4 & 36 weeks & 1 & 7.7 \\
\hline Total & 13 & 100 \\
\hline
\end{tabular}


Table 2 shows that out of 13 respondents, 6 (46.2\%) had 32 weeks' gestation.

Table 3. Frequency Distribution of Respondents by Pregnancy Frequency in Korong Lubuk Alung Market, the working area of the Lubuk Alung Health Center in 2017

\begin{tabular}{|l|l|l|l|}
\hline No & $\begin{array}{l}\text { Pregnancy } \\
\text { Frequency }\end{array}$ & Frequency & $\%$ \\
\hline 1 & 1 tme & 3 & 23.1 \\
\hline 2 & 2 time & 6 & 46.2 \\
\hline 3 & 3 time & 3 & 23.1 \\
\hline 4 & 4 time & 1 & 7.7 \\
\hline Total & 13 & 100 \\
\hline
\end{tabular}

Table 3 It can be seen that from 13 respondents, 6 people $(46.2 \%)$ had 2 times the frequency of pregnancy.

Table 4. Frequency Distribution of Anxiety Levels The mother before (pretest) was given hypnobrithing techniques in Korong Lubuk Alung Market working area of the Lubuk Alung Health Center in 2017

\begin{tabular}{|l|l|l|l|}
\hline No & Anxiety Level & Frequency & $\%$ \\
\hline 1 & There is no anxiety & 0 & 0 \\
\hline 2 & Mild anxiety & 4 & 30.8 \\
\hline 3 & Medium anxiety & 6 & 46.1 \\
\hline 4 & Severe anxiety & 1 & 7.7 \\
\hline 5 & Very heavy anxiety & 2 & 15.4 \\
\hline Total & 13 & 100 \\
\hline
\end{tabular}

Table 4 shows that can be explained that the results of univariate analysis of variable levels of anxiety of pregnant women before (pretest) were given hypnobrithing techniques were 6 respondents $(46.1 \%)$ with moderate anxiety levels.

Table 5. Distribution of the average score of the level of maternal anxiety before pretest given hypnobrithing techniques in Korong Pasar Lubuk Alung the working area of the Lubuk Alung Health Center in 2017

\begin{tabular}{|l|l|l|l|l|l|}
\hline Variable & Mean & SD & Min & Max & N \\
\hline $\begin{array}{l}\text { Mother's } \\
\text { anxiety level } \\
\text { Before giving } \\
\text { hypnobrithing } \\
\text { techniques }\end{array}$ & 25,38 & 9,377 & 16 & 45 & 13 \\
\hline
\end{tabular}

Table 5 shows that can be explained the level of maternal anxiety before (Pretest) was given hypnobrithing techniques in the Lubuk Alung Market Korong Lubuk Alung Puskesmas working area has an average (Mean) score of 25.38 with the lowest score of 16 and the highest score of 45 .
Table 6. Frequency Distribution of Mother's Anxiety Level after (posttest) was given hypnobrithing technique in Korong Lubuk Alung Market working area of Lubuk Alung Health Center in 2017

\begin{tabular}{|l|l|l|l|}
\hline No & Anxiety Level & Frekuensi & $\mathbf{\%}$ \\
\hline 1 & There is no anxiety & 1 & 7.7 \\
\hline 2 & Mild anxiety & 7 & 53.8 \\
\hline 3 & Medium anxiety & 3 & 23.1 \\
\hline 4 & Severe anxiety & 2 & 15.4 \\
\hline 5 & Very heavy anxiety & 0 & 0 \\
\hline Total & 13 & 100 \\
\hline
\end{tabular}

\section{B. Discussion}

The Level of maternal anxiety after (posttest) Given Hypnobrithing Techniques in Korong Lubuk Alung Market the working area of Lubuk Alung Health Center in Pariaman City in 2017 Based on table 7, it can be explained that the results of univariate analysis of posttest anxiety level variables after being given hypnobrithing techniques in the Lubuk Alung Market Korong Lubuk Alung Puskesmas working area have an average score of maternal anxiety levels of 21.08 points.

The results of this study indicate that there was a decrease in anxiety levels due to intervention in the form of hypnobrithing techniques. Hypnobirthing is one way to prepare for a natural, comfortable, and smooth delivery so that it doesn't feel pain. Even before a pregnant woman, if she has trauma, it is recommended to undergo self healing / self hypnosis, so that all trauma and negative feelings can be eliminated.

Generally, hypnobirthing is undertaken starting in the third trimester, although some mothers have experienced it earlier Hypnobirthing is a natural effort to prepare for labor by reprogramming the pain record that has been recorded in the subconscious soul.

Relaxation is the basis for doing hypnobirthing, coupled with affirmations and visualization techniques. The affirmation technique is done by repeating positive sentences, for example the birth process runs naturally, comfortably, and smoothly. The affirmation sentence is "prayer" so, say comfortably not without pain, smoothly not fast. Based on the results of the study also showed that of the 13 people given hypnobirthing interventions turned out to show a decrease, which found 1 respondent apparently did not experience anxiety, 7 people experienced mild anxiety, 3 people experienced moderate anxiety, 2 people experienced severe anxiety and none again who experience severe anxiety. According to the assumption that the hypnobirthing technique was able to reduce the level of anxiety of some respondents, even though there were 5 people who did not experience changes in anxiety levels. This is caused by the lack of concentration made by 
respondents when doing this technique, so it does not cause a reaction to changes in their anxiety level.

The Effect of Hypnobrithing Techniques on Anxiety Levels of Trimester III Pregnant Women in Korong Lubuk Alung Market, the working area of the Lubuk Alung Health Center in 2017. The results of research conducted by researchers found that there is an influence of hypnobrithing techniques on anxiety levels, this can be seen in table 4.8 shows the average (Mean) score of increasing maternal anxiety levels of 4.308 and can conclude there are differences in the average (Mean) level of anxiety mothers during before and after being given hypnobrithing techniques.

Statistical test results using the t-test obtained $\rho$ value $=0.001(\alpha=0.05)$, which means $\rho$ value is smaller than $\alpha$. As for the $t$ test calculation, there is a result that $t$ arithmetic is 5,067. Furthermore, the results of $t$ arithmetic compared with $t$ table, where the table uses degrees of freedom $(\mathrm{df}=\mathrm{db}=\mathrm{dk})=\mathrm{n}-1=13-1=$ 12. $\mathrm{T}$ table obtained is 2,179 , while $\mathrm{t}$ count obtained is 5,067. From this comparison it can be seen that $t$ arithmetic is greater than $\mathrm{t}$ table, which means that statistically is Ho is rejected or $\mathrm{Ha}$ is accepted where there is a difference in the average (Mean) level of maternal anxiety statistically before and after intervention in hypnobrithing techniques. After doing a statistical test using the t-test, the value of $\rho$ value $=$ $0.001, \alpha=0.05$, which means that significantly shows the hypothesis is accepted and there are significant changes in the increase in anxiety levels of mothers who have been given intervention.

There is an increase in the level of maternal anxiety between before (pretest) and after (posttest) due to the treatment given that is prior to posttest pregnant women have not been given hypnobrithing techniques for 3 weeks. While after (posttest) the mother has been given hypnobrithing techniques for 3 weeks. This result is also strengthened by the results of a study conducted by Reni and Henny (2016) of Muhammadiyah University of Malang, with the title of the influence of hypnobrithing techniques on the level of anxiety of pregnant women during preparation for childbirth, where mothers experience a decrease in anxiety levels after intervention by providing hypnobrithing techniques. Hypnobirthing provides many benefits because it trains pregnant women to always relax, be calm and stabilize emotions. Hypnobirthing aims so that mothers can give birth comfortably and relieve the pain of childbirth without the help of any anesthesia (Andriana, 2007).

This method also emphasizes giving birth in a positive, gentle, safe way and how to achieve it easily. In the Journal of Counseling and Clinical Psychology (1990), a study of hypnobirthing was conducted in two groups of pregnant women. The first group was given breathing and relaxation exercises, the second group was given the hypnobirthing method and the results of the second group were more able to cope with pain, and seemed calm when labor and the baby were born to have high Apgar scores and also reduced depression in the postpartum period.

\section{CONCLUSION}

The results of the study found that there was an influence of hypnobrithing technique on the level of anxiety in trimester III mothers during preparation for childbirth, $\mathrm{p}$ value of 0.001 and an average (Mean) increase in the score of maternal anxiety levels in mothers after intervention amounted to 4,308. It is expected that pregnant woman should be hypnobrithing this method can be one way to overcome anxiety when facing labor.

\section{REFERENCES}

[1] Adriana, Evariny, 2007. Melahirkan Tanpa Rasa Sakit. Jakarta: PT Bhuana Ilmu Populer

[2] Defin M \& Alfin M. 2012. Melahirkan tanpa rasa sakit. Jakarta: PT Bhuana Ilmu Populer

[3] Depkes RI 2018. Asuhan persalinan normal. Jakarta JHPIEGO dan POGI

[4] Dinas Kesehatan kabupaten padang Pariaman. 2014 Rekap Laporan PWS-KIA Puskesmas Per Kabupaten Padang Pariaman 2014.

[5] Hawari. 2011. Konsep diri, harga diri, jakarta: AJI

[6] Janiwarty B \& Pieter H. Z (2012). Pendidikan Psikologi Untuk Bidan. Medan : Rapha Publishing

[7] Kuswandy L , 2014. Hypnobrithing, A Gentle Way to Give Brith. Jakarta: Pustaka Bunda 